American Journal of Infectious Diseases 6 (2): 29-33, 2010

ISSN 1553-6203

(C) 2010 Science Publications

\title{
Prevalence and Antibiotics Susceptibility of Uropathogens in Patients from a Rural Environment, Tamilnadu
}

\author{
${ }^{1,2}$ Maripandi Arjunan, ${ }^{2}$ Ali A. Al-Salamah and ${ }^{1}$ M. Amuthan \\ ${ }^{1}$ Department of Microbiology, Sri Paramakalyani, Alwarkurichi, \\ Tirunelveli, Tamil Nadu, India \\ ${ }^{2}$ Unit of Medical Bacteriology, Department of Botany and Microbiology, \\ College of Science, King Saud University, P.O. Box 2455, Riyadh, Saudi Arabia
}

\begin{abstract}
Problem statement: Urinary Tract Infections (UTIs) in human, rural environment cause significant morbidity due to insanitary condition, lack of knowledge of personal hygiene, lack of patient's compliance and economic burden. In our study, the bacterial etiologies and the resistance patterns found in human with serious UTIs and selecting optimal antimicrobial therapy. Approach: A total of 105 patients first morning mid stream urine samples, culture was done by the calibrated loop technique delivering $0.001 \mathrm{~mL}$ of urine plated on Cystine-Lactose-Electrolyte Deficient (CLED) agar, MacConkey agar and Blood agar medium (Hi Media, India) for isolation of uropathogens. All pathogens were analyzed for drug susceptibility by disk diffusion method. Results: More than $50 \%$ of them were confirmed to have UTI bacteriological positive. Women and man especially in the age group of 20-29 had higher incidence of bacterial infection. A total of 58 isolates seven different uropathogens were identified among the Escherichia coli (31\%) was dominant pathogens followed by Citrobacter spp., (20\%) and Pseudomonas aeruginosa (17.24\%). In all uropathogens antibiotics susceptibility the more active agents were norfloxacin (87.93\%), ciprofloxacin (70.68\%), gentamicin $(70.68 \%)$, nalidixic acid $(68.96 \%)$, nitrofurantoine $(60.34 \%)$ and tetracycline $(60.34 \%)$ and less active in ampicillin (8.62\%), rifampicin (37.93\%) and carbenicillin (41.37\%). Conclusion: Among commonly used antimicrobial agents for the treatment of UTI, there is a trend towards increasing resistance to ampicillin and a persistently low resistance rate to norfloxacin, ciprofloxacin and gentamicin should be consider for treatment.
\end{abstract}

Key words: Uropathogens, drug susceptility, UTI patients

\section{INTRODUCTION}

Urinary Tract Infections (UTIs) are one of the most common infectious diseases and nearly $10 \%$ of people will experience a UTI during their life time. (Delanghe et al., 2000; Hoberman and Wald, 1997) it is serious ailment in human due to the frequency, recurrence and difficulty in eradication UTI poses stiff challenge to the medical professionals. UTI is much more common in women than in men, due to anatomic and physiological reasons (Fihn, 2003). By virtue of its position urinogenital tract is more vulnerable to bacterial infections caused by both internal and external flora. It is not always possible to trace the mode of entry of bacteria into the urinary tract. Many authors have suggested four possibilities which are ascending infection, haematogenous spread and lymphogenous spread and direct extension from another organ. UTI with increased risk include infants, pregnant women and the elderly, as well as those with indwelling catheters, diabetes and underlying urologic abnormalities (Foxman and Brown, 2003). Incidence of uro-genital tract infection in hospital environment is on the rise due to cross infection and lowered immune status of the patients. Furthermore indiscriminate use of antibiotics has resulted in the emergence of drug resistant pathogens. Even though several different microorganisms can cause UTIs, including protozoan parasites, fungi and viruses, bacteria are the major causative organisms and are accountable for more than 95\% of UTI cases (Bonadio et al., 2001).

Common pathogens that have been implicated in UTIs are primarily gram-negative organisms with Escherichia coli having a more prevalence than other gram-negative pathogens include Klebsiella pneumonia, Enterobacter spp., Proteus mirabilis, Pseudomonas

Corresponding Author: Maripandi Arjunan, Unit of Medical Bacteriology, Department of Botany and Microbiology, College of Science, King Saud University, P.O. Box 2455, Riyadh, Saudi Arabia 
aeruginosa and Citrobacter spp., (McLaughlin and Carson, 2004; Llenerrozos, 2004; Mittal and Wing, 2005; Blair, 2007). Some enteric organisms such as Pseudomonas also adhere to the urinary catheter and form a biofilm on the surface, which then acts as a reservoir for growth (Shigemura et al., 2006). An accurate and prompt diagnosis of UTI is important in shortening the disease course and for preventing the ascent of the infection to the upper urinary tract and renal failure. This problem of persistent uro-tract infection is more pronounced in rural environment due to insanitary condition, lack of knowledge of personal hygiene, non availability of clinical diagnostic facilities and lack of patient's compliance. In this view we were planned to study the incidence of uro-tract infection with symptomatic evaluation of patients for UTI, assess the incidence of UTI among the population in terms of sex and age groups, to determine the causative agents of UTIs and their susceptibility patterns to commonly used antibiotics in patients.

\section{MATERIALS AND METHODS}

Sampling and patients: A total of 105 patients 40 samples from female and 65 from male with suspected urinary tract infection were screened in this study. With the help of trained nursing staff the first morning mid stream urine sample was collected and transported to the laboratory in an icepack and analyzed within $6 \mathrm{~h}$. simultaneously baseline data was collected as regards to patient identification, age, sex, provisional diagnosis with help physician. This study was conducted in a period of six months at Post graduate department of Microbiology, Sri Paramakalyani College, Tamilnadu and South India.

Isolation and identification of organisms: All the samples were midstream urine specimens and culture was done by the calibrated loop technique delivering $0.001 \mathrm{~mL}$ of urine and plated on Cystine-LactoseElectrolyte Deficient (CLED) agar, MacConkey agar and Blood agar medium(Hi Media, India). The inoculated plates were incubated at $37^{\circ} \mathrm{C}$ for $24 \mathrm{~h}$ and for $48 \mathrm{~h}$ in negative cases. A specimen was considered positive for UTI if a single organism was cultured at a concentration of $\geq 10^{5} \mathrm{cfu} \mathrm{mL}^{-1}$, or when a single organism was cultured at a concentration of $10^{4} \mathrm{cfu} \mathrm{mL}^{-1}$ and $\geq 5$ pus cell per high-power field were observed on microscopic examination of the urine (Collee et al., 1996). Bacterial identification was based on standard culture and biochemical characteristics of isolates. Gram-negative bacteria were identified by standard biochemical tests (Foxman and Brown, 2003; Foxman et al., 2000). Gram-positive microorganisms were identified with the corresponding laboratory tests: catalase, coagulase, Manitol test for Staphylococcus aureus (Andreu et al., 2005).

Susceptibility testing: Antimicrobial susceptibility of isolates was tested by the Kirby Bauer disk diffusion method (Bauer et al., 1966). Antimicrobial agents tested were nitrofurantoine $(300 \mu \mathrm{g})$, tetracycline (30 $\mu \mathrm{g})$, chloroamphinicol $(30 \mu \mathrm{g})$ representative antibiotics of quinolones such as norfloxacin (10 $\mu \mathrm{g})$, ciprofloxacin (10 $\mu \mathrm{g})$, nalidixic acid $(30 \mu \mathrm{g})$; Aminoglycosides such as gentamycin (10 $\mu \mathrm{g})$, rifampicin $(5 \mu \mathrm{g})$; Beta lactam drug such as ampicilin $(10 \mu \mathrm{g})$, penicillin $\mathrm{G}$ (1 unit) and carbenicillin $(10 \mu \mathrm{g})$ (Hi Media, India).

\section{RESULTS}

Over a 6 month period, 105 midstream urine samples from outpatients were analyzed, of which 58 $(55.23 \%)$ had significant bacteriuria. Of 105 suspected patients results presented as a sizable number patients with symptoms is found to have bacterial culture was negative (Table 1). The detail analysis of the relationship of bacterial infection with the sex and age of the patients (Table 2). The incidence was found to be more in female especially in the age groups of 20-29 than the male counter parts. A total of 65 male suspected UTI samples 29 samples were revealed positive culture of pathogens. The percentage of incidence was $44.61 \%$. Where as in female 29 out of 40 samples were positive culture the percentage of incident was $72.50 \%$.

Table 1: Symptomlogical correlation of bacterial infection in UTI

\begin{tabular}{|c|c|c|c|c|}
\hline \multirow[b]{2}{*}{ Symptoms } & \multicolumn{2}{|c|}{ Patients with positive growth and symptoms } & \multicolumn{2}{|c|}{ Patients with negative growth and positive symptoms } \\
\hline & $\mathrm{N}=56$ & Percentage & $\mathrm{N}=49$ & Percentage \\
\hline Burning micturation & 49 & 87.50 & 40 & 81.16 \\
\hline Increased frequency of urination & 36 & 64.20 & 28 & 57.14 \\
\hline Fever (Acute prelates) & 25 & 44.60 & 23 & 46.93 \\
\hline Pain in abdomen & 18 & 32.10 & 12 & 24.48 \\
\hline Difficulty in maturation & 17 & 30.40 & 0 & 0.00 \\
\hline Haematuria & 10 & 17.85 & 5 & 10.20 \\
\hline Pyuria & 29 & 51.78 & 0 & 0.00 \\
\hline
\end{tabular}


Am. J. Infect. Dis., 6 (2): 29-33, 2010

Table 2: Patient of different sex and age groups with percentage of UTI

\begin{tabular}{|c|c|c|c|c|c|c|c|c|c|}
\hline \multirow[b]{2}{*}{ Age groups } & \multicolumn{3}{|l|}{ Male } & \multicolumn{3}{|l|}{ Female } & \multirow{2}{*}{$\begin{array}{l}\text { Total no. } \\
\text { of samples } \\
(\mathrm{N}=105)\end{array}$} & \multirow{2}{*}{$\begin{array}{l}\text { Infection } \\
\text { Male and } \\
\text { Female } \\
(\mathrm{N}=58)\end{array}$} & \multirow[b]{2}{*}{$\begin{array}{l}\text { UTI } \\
\text { percentage }\end{array}$} \\
\hline & $\begin{array}{l}\text { Total number } \\
(\mathrm{N}=65)\end{array}$ & $\begin{array}{l}\text { Infection } \\
\text { number }\end{array}$ & Percentage & $\begin{array}{l}\text { Total number } \\
(\mathrm{N}=40)\end{array}$ & $\begin{array}{l}\text { Infection } \\
\text { number }\end{array}$ & Percentage & & & \\
\hline $1-10$ & 04 & 02 & 50.00 & 03 & 2 & 66.66 & 07 & 04 & 06.89 \\
\hline $20-29$ & 20 & 12 & 60.00 & 11 & 9 & 81.81 & 31 & 21 & 36.20 \\
\hline $30-39$ & 13 & 06 & 46.15 & 14 & 9 & 64.25 & 27 & 15 & 25.86 \\
\hline $40-49$ & 19 & 06 & 31.57 & 09 & 7 & 77.77 & 28 & 13 & 22.41 \\
\hline $50-60$ & 09 & 03 & 33.33 & 03 & 2 & 66.66 & 11 & 05 & 08.62 \\
\hline
\end{tabular}

Table 3: Prevalence and percentage of uropathogens isolated from different age groups

\begin{tabular}{|c|c|c|c|c|c|c|c|}
\hline \multirow[b]{2}{*}{ Organisms } & \multicolumn{5}{|c|}{ Age groups } & \multirow{2}{*}{$\begin{array}{l}\text { Total number } \\
\text { of organisms }\end{array}$} & \multirow{2}{*}{$\begin{array}{l}\text { Percentage } \\
\text { of organisms }\end{array}$} \\
\hline & $1-10$ & $14-29$ & $30-34$ & $40-49$ & $50-60$ & & \\
\hline$\overline{\text { Escherichia coli }}$ & 1 & 8 & 4 & 2 & 3 & 18 & 31.03 \\
\hline Citrobacter spp. & 2 & 3 & 4 & 2 & 1 & 12 & 20.68 \\
\hline Pseudomonas aeroginosa & 0 & 5 & 1 & 4 & $0-$ & 10 & 17.24 \\
\hline Proteus vulgaris & 0 & 4 & 3 & 1 & 0 & 8 & 13.79 \\
\hline Klebsiella aerogens & 0 & 0 & 3 & 3 & 1 & 7 & 12.06 \\
\hline Staphylococcus aureus & 0 & 0 & 0 & 1 & 0 & 1 & 1.72 \\
\hline Salmonella spp. & 1 & 1 & 0 & 0 & 0 & 2 & 3.44 \\
\hline Total & 4 & 21 & 15 & 13 & 6 & 58 & ---- \\
\hline
\end{tabular}

Table 4: Antimicrobial susceptibility rates of the tested uropathogens isolates against 11 antimicrobial agents

\begin{tabular}{|c|c|c|c|c|c|c|c|}
\hline \multirow[b]{2}{*}{ Antimicrobial agents } & \multicolumn{7}{|c|}{ Susceptibility, n/N (\%) } \\
\hline & $\begin{array}{l}\text { Escherichia coli } \\
(\mathrm{n}=18)\end{array}$ & $\begin{array}{l}\text { Citrobacter spp. } \\
(\mathrm{n}=12)\end{array}$ & $\begin{array}{l}\text { Pseudomonas } \\
\text { aeroginosa } \\
(\mathrm{n}=10)\end{array}$ & $\begin{array}{l}\text { Proteus } \\
\text { vulgaris } \\
(\mathrm{n}=8)\end{array}$ & $\begin{array}{l}\text { Klebsiella } \\
\text { aerogens } \\
(\mathrm{n}=7)\end{array}$ & $\begin{array}{l}\text { Staphylococcus } \\
\text { aureus } \\
(\mathrm{n}=1)\end{array}$ & $\begin{array}{l}\text { Salmonella } \\
\text { spp. } \\
(\mathrm{n}=2)\end{array}$ \\
\hline Norfloxacin $(10 \mu \mathrm{g})$ & $17(94.44 \%)$ & $10(83.33 \%)$ & $9(90.00 \%)$ & $7(87.50 \%)$ & $5(71.42 \%)$ & $1(100 \%)$ & $2(100 \%)$ \\
\hline Ciprofloxacin $(10 \mu \mathrm{g})$ & $14(77.70 \%)$ & $8(66.60 \%)$ & $7(70.00 \%)$ & $4(50.00 \%)$ & $6(85.71 \%)$ & $1(100 \%)$ & $1(50.00 \%)$ \\
\hline Gentamycin $(10 \mu \mathrm{g})$ & $15(83.33 \%)$ & $6(66.60 \%)$ & $8(80.00 \%)$ & $5(62.50 \%)$ & $4(57.00 \%)$ & $1(100 \%)$ & $2(100 \%)$ \\
\hline Ampicilin $(10 \mu \mathrm{g})$ & $2(11.11 \%)$ & 0 & $1(10.00 \%)$ & 0 & $2(28.57 \%)$ & 0 & 0 \\
\hline Rifampicin $(5 \mu \mathrm{g})$ & $4(22.22 \%)$ & $2(16.60 \%)$ & $7(70.00 \%)$ & $2(25.00 \%)$ & $5(71.42 \%)$ & $1(100 \%)$ & $1(50.00 \%)$ \\
\hline Penicillin G (1 unit) & 0 & 0 & 0 & 0 & 0 & 0 & 0 \\
\hline Nalidixic acid $(30 \mu \mathrm{g})$ & $13(72.22 \%)$ & $4(33.30 \%)$ & $8(80.00 \%)$ & $4(50.00 \%)$ & $5(71.42 \%)$ & $1(100 \%)$ & $1(50.00 \%)$ \\
\hline Nitrofurantoine $(30 \mu \mathrm{g})$ & $7(38.88 \%)$ & $9(75.00 \%)$ & $13(50.00 \%)$ & $4(50.00 \%)$ & 0 & 0 & $2(100 \%)$ \\
\hline Tetracycline $(30 \mu \mathrm{g})$ & $12(66.66 \%)$ & $8(66.66 \%)$ & $7(70.00 \%)$ & $3(37.50 \%)$ & $4(57.00 \%)$ & 0 & $1(50.00 \%)$ \\
\hline Chloroamphinicol $(30 \mu \mathrm{g})$ & $11(61.11 \%)$ & 0 & $5(50.00 \%)$ & 0 & $5(71.42 \%)$ & $1(100 \%)$ & $2(100 \%)$ \\
\hline Carbenicillin $(10 \mu \mathrm{g})$ & $8(44.44 \%)$ & $3(25.00 \%)$ & $2(20.00 \%)$ & 0 & $4(42.85 \%)$ & $1(100 \%)$ & $2(100 \%)$ \\
\hline
\end{tabular}

Spectrums of seven different uropathogens were isolated. It was varied importance and their distribution in patients of different sex and age groups (Table 3). Overall more than $95 \%$ of isolates were gram negative organisms. E. coli was the most frequently isolated uropathogens $(31.03 \%)$, followed by Citrobacter spp., $(20.68 \%)$ and least isolated Salmonella spp., (3.44\%) and S. aureus (1.72\%) (Table 3). A total of 11 antibiotics tested against all uropathogens among which norfloxacin, ciprofloxacin and gentamycin more effective than other antibiotics such as nitrofurantoine and ampicillin. The rates of resistance of isolates to a panel of antibiotics are routinely used to treat UTI infections, are shown in (Table 4) E. coli as the predominant cause of UTI, showed the highest percentage of resistance to penicillin in $100 \%$ and ampicillin in $93.1 \%$ and the lowest resistance to norfloxacin in $5.56 \%$. Citrobacter spp., as the second most prevalent pathogen of UTI displayed a similar resistance pattern and were resistant to ampicillin in $100 \%$ of cases and susceptible to norfloxacin in $83.33 \%$ of cases. Followed by $P$. aeruginosa and $P$. vulgaris showed the highest antibiotic resistance rate and was significantly resistant to most of the antibiotics (Table 4). In this study, S. aureus was responsible for about $1.72 \%$ of UTI cases and were resistant to penicillin, ampicillin, nitrofurantoine and tetracycline in $100 \%$ respectively.

\section{DISCUSSION}

Infection of the urinary tract is one of the most common infectious diseases and it would affect all age groups peoples including men, women and children in worldwide (McLaughlin and Carson, 2004; Llenerrozos, 2004; Blair, 2007). In this study, of 105 
patients with complaint from who urine samples were taken, only $52.83 \%$ had a bacterial urinary tract infection. This is possibly because UTI symptoms are not a reliable indicator of infection. Early diagnosis and timely and appropriate antimicrobial treatment are considered key factors for eliminate the pathogen, to prevent urosepsis and to reduce the risk of renal scarring. Urinary Tract Infection (UTI) can be either symptomatic or asymptomatic (Macejko and Schaeffer, 2007). Patients with significant bacteriuria who have symptoms referable to the urinary tract are said to have symptomatic bacteriuria (Hooton et al., 1996). Asymptomatic bacteriuria is a condition characterized by bacteriuria without classical symptoms attributable to the urinary tract (Nicolle, 1997). In our studies the incidence of infection was highest in the age group of 2029 followed by 30-39. This finding correlates with the reports of earlier workers which include (Macejko and Schaeffer, 2007). Most UTIs are caused by bacteria and $E$. coli is the most common uropathogen detected in above $30 \%$ cases. Citrobacter spp., was isolated in $20 \%$ of cases and other occasional pathogens include S. aureus, Salmonella spp., $P$. mirabilis and $K$. aerogens 2-48. Similar results observed Taneja et al. (2010) investigated a total of 1974 clean catch midstream urine samples from which significant bacteriuria was found in 558 samples (28.3\%). Common uropathogens isolated were Escherichia coli (47.1\%), Klebsiella spp. (15.6\%), Enterococcus fecalis (8.7\%), members of tribe Proteae (5.9\%), P. aeruginosa (5.9\%) and Candida spp., (5.5\%).whereas others (Tambekar et al., 2009) investigated a total of 174 urine samples were analyzed from which, 68 found to be significant bacteriuria with E. coli (59\%), followed by Pseudomonas aeruginosa (15\%), K. pneumoniae (10\%), P. mirabilis (9\%), S.aureus (6\%) and C. freundii $(1 \%)$. The urinary tract infections were found to most frequently in female $(63 \%)$ than male $(37 \%)$. On the other hand Amin et al. (2009) reported that the urine culture bacteriological positive were $68 \%$ females and $32 \%$ males. The most isolated bacterium was $E$. coli with frequency rate of $59 \%$. The other bacteria were Klebsiella spp. (11.6\%), Enterobacter spp. (9.8\%), Pseudomonas spp. (7.2\%), Proteus spp. (2.9\%), Acinetobacter spp. (2.7\%), coagulase positive Staphylococci (2.2\%), coagulase negative Staphylococci (2.3\%), Citrobacter spp. (1.3\%) and Streptococci $\alpha$ hemolytic (1.1\%). Wazait et al. (2003) has reported still higher incidence of Escherichia coli $(47.30 \%)$ in urine samples. The presence and distribution of other pathogens namely $P$. vulgaris, $K$. aerogens, $S$. aureus correlate with earlier reports (Ronald, 2002) it is interesting to note that only few have reported the presence and significance of Citrobacter spp., in UTI (Chawla et al., 1998; Kim et al., 2003). Recurrence is an inevitable consequence of UTI. Frequent and abrupt emergence of drug resistant strains is attributed as a major reason for this. Most of the isolates had exhibited resistance to common antibiotics like ampicilin, tetracycline and carbenicilin. Tseng et al. (2008) from UTI recovered all bacteria showed the highest degree of resistance to ampicillin, cefalothin. The Gram-negative bacilli isolated from UTI were sensitive to amikacin and, ciprofloxacin (83-100\%) and Gram-positive cocci were sensitive to kanamicin and tobramicin (100\%). (Nicolle, 2002) has remarked that this increase in resistance may be due to improper treatment and indiscriminate use of antibiotics.

\section{CONCLUSION}

In conclusion, the present studies the incidence of urinary tract infection was high in the age group of 2029. A total of 58 isolates seven different uropathogens were identified among the $E$. coli was dominant pathogens. The drugs norfloxacin and ciprofloxacin, the relatively floor quinolones were found to be the most effective against uropathogenic isolates followed by gentamycin and nalidixic acid.

\section{ACKNOWLEDGMENT}

We thank Dr. A. Monakar for his kindly suggestion and help during this study and also thank Mr. Muthukrishnan Microbiologist for his excellent cordial help in supplying the clinical specimen and data for the patients.

\section{REFERENCES}

Amin, M., M. Manijeh and P. Zohreh, 2009. Study of bacteria isolated from urinary tract infections and determination of their susceptibility to antibiotics. Jundishapur J. Microbiol., 2: 118-123. http://jjm.ajums.ac.ir/_jjm/documents/Amin11823.pdf

Andreu, A., J.I. Alos JI, M. Gobernado, M. Fdela Rosa and J.A. Garcia-Rodriguez, 2005. Etiology and antimicrobial susceptibility among uropathogens causing community-acquired lower urinary tract infections: A nationwide surveillance study. Enferm. Infect. Microbiol. Clin., 23: 4-9. PMID: 15701325

Bauer, A.W., W.M. Kirby, J.C. Sherris and M. Turck, 1966. Antibiotic susceptibility testing by a standardized single disk method. Am. J. Clin. Pathol., 45: 493-496. PMID: 5325707 
Blair, K.A., 2007. Evidence based urinary tract infection across the life span: current updates. J. Nurse Pract., 3: 629-632. DOI: 10.1016/j.nurpra.2007.07.020

Bonadio, M., M. Meini, P. Spitaler and C. Gigli, 2001. Current microbiological and clinical aspect of urinary tract infection. Eur. Urol., 40: 439-445. DOI: $10.1159 / 000049813$

Chawla, J.C., C.L. Clayton and D.J. Stickler, 1998. Antiseptics in the long-term urological management of patients by intermittent catheterization. Br. J. Urol., 62: 289-294. PMID: 3056565

Collee, J.G., R.S. Miles and B. Watt, 1996. Tests for the Identification of Bacteria. In: Mackie and Mc Cartney Practical Medical Microbiology, Collee, J.G., A.G. Fraser, B.P. Marmion and A. Simmons (Eds.). Churchill Livingstone Inc, London, ISBN: 0470114851, pp: 433.

Delanghe, J.R., T.T. Kouri, A.R. Huber, K. HannemannPohl and W.G. Guder et al., 2000. The role of automated urine particle flow cytometry in clinical practice. Clin. Chim. Acta, 301: 1-18. PMID: 11020458

Fihn, S.D., 2003. Acute uncomplicated urinary tract infection in women. N. Engl. J. Med., 349: 259-266. http://content.nejm.org/cgi/content/full/349/3/259

Foxman, B. and P. Brown, 2003. Epidemiology of urinary tract infections: Transmission and risk factors, incidence and costs. Infect. Dis. Clin. North Am., 49: 53-70. PMID: 12848468

Foxman, R., B.H. D'Arcy and B. Gillespie, 2000. Urinary tract infection: Self-reported incidence and associated costs. Ann. Epidemiol., 10: 509-515. PMID: 11118930

Hoberman, A. and E.R. Wald, 1997. Urinary tract infections in young febrile children. Pediatr. Infect. Dis. J., 16: 11-17. PMID: 9002094

Hooton, T.M., D. Scholes, J.P. Hughes, C. Winter, P.L. Roberts et al., 1996. A prospective study of risk factors for symptomatic urinary tract infection in young women. N. Engl. J. Med., 335: 468-74. http://content.nejm.org/cgi/content/short/335/7/468

Kim, B.N., J.H. Woo, J. Ryu and Y.S. Kim, 2003. Resistance to extended-spectrum cephalosporins and mortality in patients with Citrobacter Freundii bacteremia. Infection, 19: 202-207. PMID: 14562942

Llenerrozos, H.J., 2004. Evidence-based management of urinary tract infections across the lifespan: Management. Clin. Fam. Pract., 6: 157-173. http://www.medscape.com/viewarticle/565611_4
Macejko, A.M. and A.J. Schaeffer, 2007. Asymptomatic bacteriuria and symptomatic urinary tract infections during pregnancy. Urol. Clin. North Am., 34: 35-42. PMID: 17145359

McLaughlin, S.P. and C.C. Carson, 2004. Urinary tract infections in women. Med. Clin. North Am., 88: 417-429. PMID: 15049585

Mittal, P. and D.A. Wing, 2005. Urinary tract infections in pregnancy. Clin. Perinatol., 32: 749-764. PMID: 16085031

Nicolle, L.E., 1997. Asymptomatic bacteriuria in the elderly. Infect. Dis. Clin. North Am., 11: 647-662. PMID: 9378928

Nicolle, L.E., 2002. Resistant pathogens in urinary tract infections. J. Am. Geriat. Soc., 50: 230-235. DOI: 10.1046/j.1532-5415.50.7s.3.x

Ronald, A., 2002. The etiology of urinary tract infection: Traditional emerging pathogens. Am. J. Med., 113: 14-19. http://www.amjmed.com/article/S0002-9343 (02)01055-0/abstract

Shigemura, K., A. Arakawa, Y. Sakai, S. Kinoshita and K. Tanaka et al., 2006. Complicated urinary tract infection caused by Pseudomonas aeruginosa in a single institution. Int. J. Urol., 13: 538-542. DOI: 10.1111/j.1442-2042.2006.01359.x

Tambekar, D.H., D.V. Dhanorkar, S.R. Gulhane, V.K. Khandelwal and M.N. Dudhane, 2009. Antibacterial susceptibility of some urinary tract pathogens to commonly used antibiotics. Afr. J. Biotech., 5: 1562-1565. http://ajol.info/index.php/ajb/article/viewFile/4316 2/26705

Taneja, N., S.S. Chatterjee, S. Meenakshi, S. Surjit and S. Meera, 2010. Pediatric urinary tract infections in a tertiary care center from north India. Indian J. Med. Res., 131: 101-105. PMID: 20167982

Tseng, M.H., W.T. Lo, W.J. Lin, C.S. Teng and M.L. Chu et al., 2008. Changing trend in antimicrobial resistance of pediatric uropathogens in Taiwan. Pediatr. Int., 50: 797-800. PMID: 19067894

Wazait, H.D., H.R.H. Patel, V. Veer, M. Kelsey and J.H.P. van der Meulen et al., 2003. Catheterassociated urinary tract infections: Prevalence of uropathogens and pattern of antimicrobial resistance in a UK hospital. Brit. J. Urol., 91: 806-809. PMID: 12780837 